\title{
POPULATION GROWTH OF Rhopalosiphum padi L. (HOMOPTERA: APHIDIDAE) ON DIFFERENT CEREAL CROPS FROM THE SEMIARID PAMPAS OF ARGENTINA UNDER LABORATORY CONDITIONS
}

\author{
Lilian R. Descamps ${ }^{1 *}$, and Carolina Sánchez Chopa $^{1,2}$
}

\begin{abstract}
The bird cherry-oat aphid Rhopalosiphum padi L. (Homoptera: Aphididae) is one of the main pests in a number of crops in the semiarid Pampas of Argentina. In the present study, the effect of different host plants, including Triticum aestivum L., $\times$ Triticosecale Wittm., Hordeum vulgare L., Hordeum distichum L., Avena sativa L., and Secale cereale L. on biological parameters of $R$. padi L. was studied in the laboratory at $24 \pm 1{ }^{\circ} \mathrm{C}, 65 \pm 10 \% \mathrm{RH}$ and a $14: 10$ photoperiod. Longevity, intrinsic rate of natural increase $\left(r_{m}\right)$, net reproductive rate $\left(R_{0}\right)$, mean generation time $(T)$, doubling time (DT), and finite rate of increase $(\lambda)$ of the bird cherry-oat aphid on the different cereal crops were estimated. Differences in fertility life table parameters of $R$. padi among host plants were analyzed using pseudo-values, which were produced by Jackknife re-sampling. Results indicated that beer barley might be the most suitable food for $R$. padi due to greater adult longevity (20.88 d), higher fecundity (41 nymphs female $\left.\mathrm{e}^{-1}\right)$, higher intrinsic rate of natural increase $\left(0.309\right.$ females female $\left.^{-1} \mathrm{~d}^{-1}\right), 1$ lower doubling time (2.24), and lower nymphal mortality (22.2\%). Therefore, it can be concluded from the present study that $R$. padi prefers beer barley for fast and healthy development over other cereal crops.
\end{abstract}

Key words: Intrinsic rate, life span, bird cherry-oat aphid, winter crops.

$\mathrm{A}$ phids are a serious insect pest problem in many cereal-growing regions of the world, and they feed on phloem sap and infect plants with harmful viruses (Blackman and Eastop, 2000). Among the numerous aphid species found in cereals, the bird cherry-oat aphid, Rhopalosiphum padi, is considered to be one of the major pests in the semiarid Pampas of Argentina and in other grain-growing areas of the world (Gianoli, 2000; Hansen, 2000; Schotzko and Bosque-Pérez, 2000; Östman et al., 2001; Qureshi and Michaud, 2005; Bailey, 2007; Hill, 2008).

Although this species can remove considerable amounts of liquid and nutrients from phloem, and strong infestations can sometimes lead to leaf contortion, the direct effect on grain yield is generally minor, especially if plants are young when they are infested. The insect causes the most damage by transmitting a number of viruses, especially Barley yellow dwarf virus (BYDV), for which it is the most important vector (Riedell et al., 2003; Jiménez-Martínez et al., 2004; Fabre et al., 2006; Borer et al., 2009).

Phloem sap only contains small amounts of the amino acids that the aphids need, so they must consume large volumes of it, meaning that they subsequently have to

${ }^{1}$ Universidad Nacional del Sur, Departamento de Agronomía, San Andrés s/n, Altos Palihue, 8000 Bahía Blanca, Argentina. *Corresponding author (descamps@criba.edu.ar).

${ }^{2}$ CONICET Consejo Nacional de Investigaciones Científicas y Técnicas, Av. Rivadavia 1917 C1033AAJ, Argentina.

Received: 15 December 2010.

Accepted: 7 April 2011. excrete excess liquids and sugars. If population densities are high, this excretion can create a sticky film on plant surfaces that can reduce photosynthesis and promote the growth of sooty mold (Blackman and Eastop, 2000).

The strategies to control any insect pest generally need a detailed study of the life history parameters (Hasan and Ansari, 2010). Life tables are powerful tools for analyzing and understanding the impact that an external factor has upon the growth, survival, reproduction, and rate of increase of an insect population (Soleimannejad et al., 2010; Soufbaf et al., 2010). Knowledge of biology and population growth potential is crucial for studying its dynamics and establishing management tactics for pest control. Biological parameters, such as the duration of developmental stages and population growth obtained from fertility life tables, are important for that knowledge (La Rossa and Kahn, 2003).

The main objective of this research was to determine the effects of different cereal crops on reproduction, survival, longevity, and the intrinsic rate of increase of $R$. padi under controlled environmental conditions.

\section{MATERIALS AND METHODS}

\section{Plant materials}

Six winter cereals commonly grown in the semiarid Pampas of Argentina were selected for this study: wheat (Triticum aestivum L.cv. Biointa), triticale ( $\times$ Triticosecale Wittm. cv. Yagán), forage barley (Hordeum vulgare L. cv. Mariana), beer barley (Hordeum distichum L. 
cv. Josefina), oat (Avena sativa L. cv. Violeta), and rye (Secale cereale L. cv. Fausto).

The cereal seeds were obtained from the Instituto Nacional de Tecnología Agropecuaria (INTA) in Bordenave, Argentina and were planted individually in $10-\mathrm{cm}$ diameter clay pots filled with Entic Haplustoll soil fertilized at commercial rates (Soil Survey Staff, 1999). The plant grew at $24 \pm 1{ }^{\circ} \mathrm{C}, 65 \pm 10 \% \mathrm{RH}$, and a photoperiod of 14:10 h (L:D).

\section{Insects}

Rhopalosiphum padi were obtained from colonies established in wheat crop field collections and maintained on wheat cv. Biointa, triticale cv. Yagán, forage barley cv. Mariana, beer barley cv. Josefina, oat cv. Violeta, and rye $\mathrm{cv}$. Fausto in wood-framed cages $(35 \times 35 \times 70 \mathrm{~cm})$ in the laboratory under the aforementioned conditions. The aphid population was reared for several generations before experiments were conducted. The effect of host plants on fecundity, life table parameters, and development of $R$. padi was studied in the laboratory at $24^{\circ} \mathrm{C}$ and $65 \pm 10 \% \mathrm{RH}$.

\section{Development, fecundity, and life table parameters}

To evaluate developmental time and survivorship of immature stages, fecundity and longevity of adults, approximately 50 adult apterous aphids were randomly chosen from the rearing colonies and placed on the leaf surface, each confined inside a clip cage $(1 \mathrm{~cm}$ diameter $\times 1$ $\mathrm{cm}$ height) to prevent escape and parasitism with a suitable paintbrush. They were permitted to produce nymphs for $24 \mathrm{~h}$ and then the adult aphids were eliminated from the leaf clip cage. Each plant received one aphid nymph that was confined to the first true leaf. These nymphs were monitored daily to assess the aphid's performance on winter cereals. After maturity and the beginning of reproduction, adult mortality and fecundity were recorded daily, and the offspring were removed from each leaf cage until each adult aphid died. We estimated the fecundity of 20 adult aphids for each cereal in this study.

Life tables were constructed based on Birch (1948) and Southwood and Henderson (2000). The survival rate for adults from birth to age $\mathrm{x}\left(\mathrm{l}_{\mathrm{x}}\right)$, fecundity $\left(\mathrm{m}_{\mathrm{x}}\right.$, total number of offspring produced at age $\mathrm{x}$ ), and $\mathrm{m}_{\mathrm{x}}$ (female offspring produced at age $\mathrm{x}$ ) were measured according to Birch (1948). From these data, the intrinsic rate of increase $\left(r_{m}\right.$, females female $\left.{ }^{-1} \mathrm{~d}^{-1}\right)$, net reproductive rate $\left(\mathrm{R}_{0}\right.$, females female $^{-1}$ generation $\left.^{-1}\right)$, finite rate of increase $(\lambda$, individuals females $\left.^{-1} \mathrm{~d}^{-1}\right)$, mean generation time $\left(\mathrm{T}, \ln \left(\mathrm{R}_{0}\right) / \mathrm{r}_{\mathrm{m}}\right)$, and doubling time (DT, d) were estimated with software written for this purpose (La Rossa and Kahn, 2003).

\section{Data analysis}

Differences in fecundity, longevity, and development time were tested by ANOVA. If significant differences were detected, mean values were compared by the least significant difference (LSD). The following parameters were also calculated for survivorship and fertility table: (a) Net reproductive rate $\left(R_{0}\right)$ referred to as the "carrying capacity" of the average insect under defined environmental conditions. Information on a population's multiplication rate in one generation is obtained by the following equation:

$$
\mathrm{R}_{0}=\Sigma 1_{\mathrm{x}} \mathrm{m}_{\mathrm{x}}
$$

(b) Mean generation time (T) is the mean period between the birth of the parent and the birth of their offspring.

$$
\mathrm{T}=\ln \mathrm{R}_{0} / \mathrm{r}_{\mathrm{m}}
$$

(c) Intrinsic rate of increase $\left(r_{m}\right)$ is defined as the instantaneous rate of increase of a population in a time unit under a given set of ecological conditions (Birch, 1948). The intrinsic rate of increase $\left(r_{m}\right)$ can be calculated by the following equations:

$$
\begin{aligned}
& r_{m}=\left(\log _{e} R_{0}\right) / T \text { (for rough estimation) } \\
& e^{-r x} 1_{x} m_{x}=1 \text { (for accurate estimation) }
\end{aligned}
$$

where $\mathrm{R}_{0}$ represents net reproductive rate and $\mathrm{T}$ represents mean generation time.

(d) Finite rate of increase $(\lambda)$ provides information about population multiplication in a time unit (Birch 1948).

$\lambda=\mathrm{e}^{\mathrm{rm}}$ Taking the $\log$ on both sides, we get $\ln \lambda=\mathrm{r}$

(e) Doubling time (DT) is defined as the time required for the population to double and is calculated as follows:

$$
\mathrm{DT}=\ln 2 / \mathrm{r}_{\mathrm{m}}
$$

Differences in $r_{m}$ and other life table parameters were tested for significance and the variance was estimated by the Jackknife method (Maia De et al., 2000). Jackknife pseudo-values were calculated with a computer program (La Rossa and Kahn, 2003) and the mean Jackknife pseudovalue for each treatment was subjected to ANOVA. Least significant difference (LSD) was employed to compare $r_{m}$ and other life table parameters on different cereal crops.

\section{RESULTS}

\section{Development time, longevity and fecundity}

The developmental time of viviparous apterae (mean number of days from birth to first reproduction) was not significantly influenced by different host plants $(\mathrm{P}>$ $0.05)$. Nymphs reared on rye had a longer developmental time $(6.5 \mathrm{~d})$ than those reared on any other winter cereal, whereas offspring living on wheat demonstrated a shorter developmental value (5.1 d) (Table 1 ).

The highest percentage of nymphal mortality was found on wheat and the lowest on beer barley, triticale, and rye (Table 1, Figure 1).

Life expectancy of 1-d-old nymphs on the first day was $21.7,21.4,19.8,18.8,17.05$, and $17 \mathrm{~d}$ on triticale, beer barley, rye, oat, wheat, and forage barley, respectively (Figure 2).

Winter cereals showed no significant effect on aphid longevity or total offspring per female $(\mathrm{P}>0.05)$. However, significant effects were observed for the means of offspring produced per female per day $(\mathrm{P}<0.05)$ (Table1, Figure 1). 
Table 1. Nymphal mortality, developmental time, adult longevity, and fecundity of Ropalosiphum padi reared on six winter cereals.

\begin{tabular}{|c|c|c|c|c|c|}
\hline \multirow[b]{2}{*}{ Winter cereal } & \multicolumn{5}{|c|}{ Developmental data $(\text { mean } \pm \mathrm{SD})^{1,2}$} \\
\hline & $\begin{array}{l}\text { Nymphal } \\
\text { mortality }\end{array}$ & $\begin{array}{l}\text { Developmental } \\
\text { time }\end{array}$ & Adult longevity & $\begin{array}{l}\text { Total number of } \\
\text { offspring/female }\end{array}$ & $\begin{array}{c}\text { Number of } \\
\text { offspring/reproduction day }\end{array}$ \\
\hline & $\%$ & $\longrightarrow$ & - & & \\
\hline Hordeum distichum & 22.2 & $6.29 \pm 0.23 \mathrm{a}$ & $20.88 \pm 2.65 \mathrm{a}$ & $41 \pm 5.53 \mathrm{a}$ & $2.59 \pm 0.33 b$ \\
\hline Hordeum vulgare & 33.3 & $6.11 \pm 0.51 \mathrm{a}$ & $16.50 \pm 2.28 \mathrm{a}$ & $31.83 \pm 5.81 \mathrm{a}$ & $1.93 \pm 0.24 \mathrm{ab}$ \\
\hline Triticum aestivum & 44.4 & $5.10 \pm 0.47 \mathrm{a}$ & $16.55 \pm 3 a$ & $39.60 \pm 7.59 a$ & $1.99 \pm 0.19 \mathrm{ab}$ \\
\hline Triticale & 22.2 & $6.27 \pm 0.4 \mathrm{a}$ & $21.27 \pm 2.66 \mathrm{a}$ & $30 \pm 4.50 \mathrm{a}$ & $1.51 \pm 0.18 \mathrm{a}$ \\
\hline Avena sativa & 33.3 & $5.38 \pm 0.29 a$ & $18.30 \pm 1.78 \mathrm{a}$ & $31.90 \pm 4.60 \mathrm{a}$ & $1.47 \pm 0.1 \mathrm{a}$ \\
\hline Secale cereale & 22.2 & $6.50 \pm 0.33 \mathrm{a}$ & $18.72 \pm 2.25 \mathrm{a}$ & $34.58 \pm 3.9 \mathrm{a}$ & $2.21 \pm 0.24 b$ \\
\hline
\end{tabular}

${ }^{1} \mathrm{SD}$ : Standard error. Means within columns followed by the same letters are not significantly different (LSD, P $\left.>0.05\right)$.

${ }^{2}$ Sample size is 20 (apterous aphid tested) for each parameter.
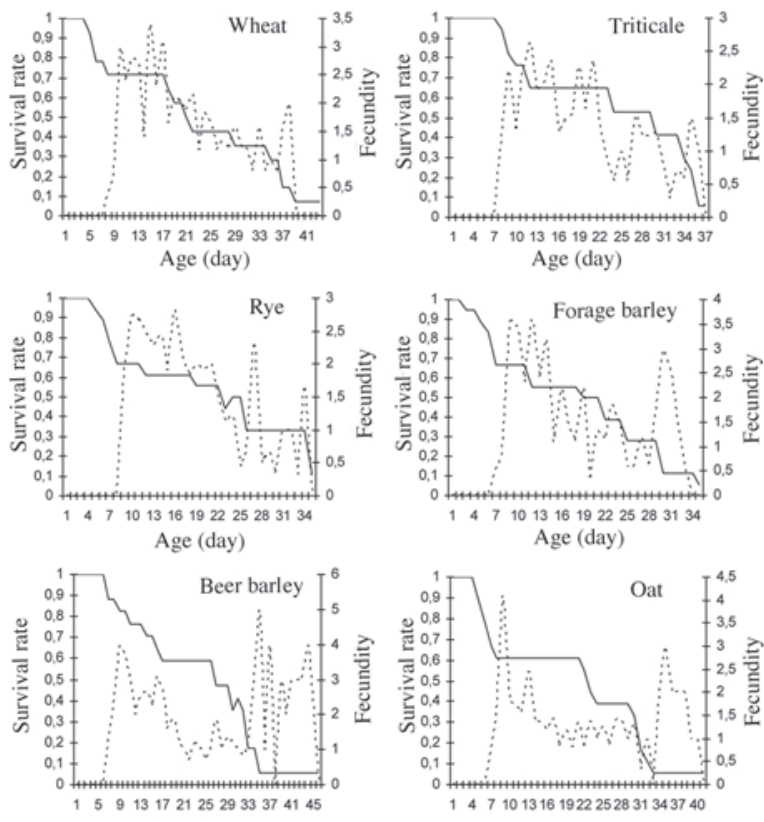

Age (day)

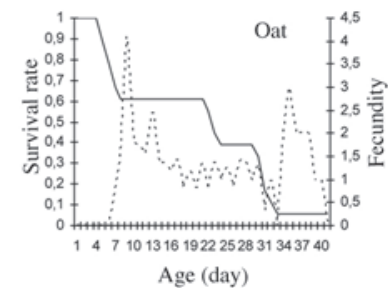

Figure 1.Daily survival rate (_) and fecundity (-------) of Rhopalosiphum padi on six winter cereals under laboratory conditions.

Rhopalosiphum padi had the longest average adult lifespan on triticale $(21.27 \mathrm{~d})$ and the shortest on forage barley (16.50 d) (Table 1). The mean number of offspring per female was the highest on beer barley (41) and the lowest on triticale (30) (Table 1); the means of offspring produced per female per day was higher on beer barley ( $\mathrm{P}$ $<0.05$ ) (Table 1, Figure 1).

\section{Life table parameters}

The value of the aphid net reproductive rate $\left(\mathrm{R}_{0}\right)$ did

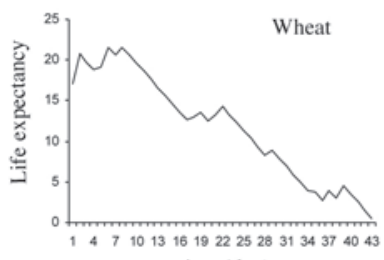

Age (day)
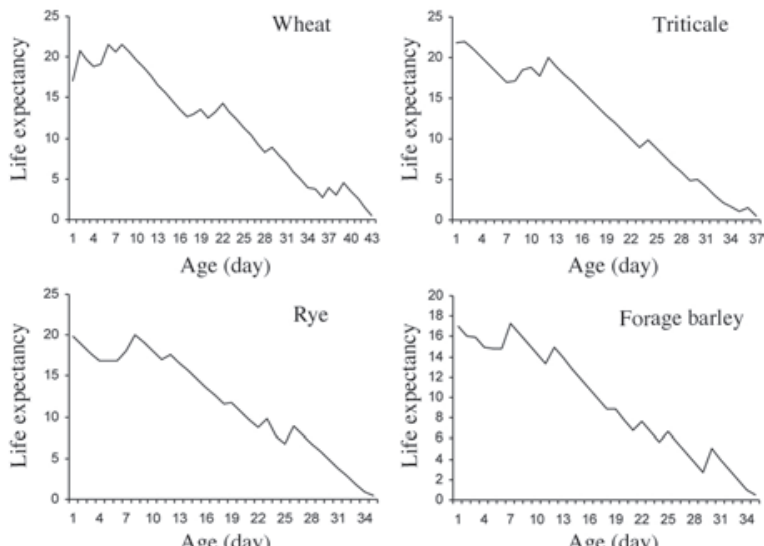

Age (day)
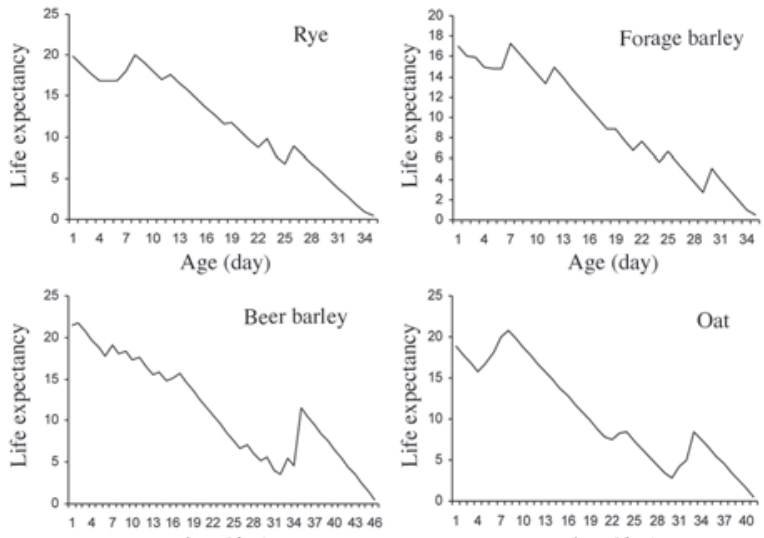

Age (day)

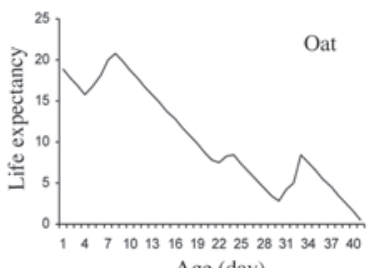

Age (day)

Figure 2. Life expectancy of Rhopalosiphum padi on six winter cereals under laboratory conditions.

not show any difference among the cereals tested $(\mathrm{P}>$ $0.05)$. Aphids fed on beer barley had the highest $R_{0}$ value (38.97 aphids aphid ${ }^{-1}$ ) while those on forage barley and oat had the lowest value (21.46 and 21.52 aphids aphid ${ }^{-1}$, respectively) (Table 2). The mean generation time (T) values of $R$. padi on oat, rye, and wheat were higher than on beer barley and forage barley $(\mathrm{P}<0.05)$. In addition, doubling times (DT) and the finite rate of increase $(\lambda)$ of the bird cherry-oat aphid population did not differ among winter cereals $(\mathrm{P}>0.05)$ (Table 2$)$.

Table 2. Life table parameters of Ropalosiphum padi reared on six winter cereals.

\begin{tabular}{|c|c|c|c|c|c|}
\hline \multirow[b]{2}{*}{ Winter cereal } & \multicolumn{5}{|c|}{ Parameter $($ mean \pm SD) } \\
\hline & $\mathrm{R}_{0}$ & $\mathrm{~T}(\mathrm{~d})$ & DT (d) & $\lambda$ & $\mathrm{r}_{\mathrm{m}}$ \\
\hline Hordeum distichum & $38.97 \pm 6.79 a$ & $11.96 \pm 0.62 \mathrm{a}$ & $2.24 \pm 0.13 \mathrm{a}$ & $1.36 \pm 0.02 \mathrm{a}$ & $0.309 \pm 0.01 b$ \\
\hline Hordeum vulgare & $21.46 \pm 5.28 \mathrm{a}$ & $11.83 \pm 0.39 \mathrm{a}$ & $2.62 \pm 0.25 \mathrm{a}$ & $1.29 \pm 0.03 \mathrm{a}$ & $0.261 \pm 0.02 \mathrm{ab}$ \\
\hline Triticum aestivum & $28.24 \pm 7.35 \mathrm{a}$ & $14.21 \pm 0.59 \mathrm{c}$ & $2.90 \pm 0.21 \mathrm{a}$ & $1.26 \pm 0.02 \mathrm{a}$ & $0.238 \pm 0.01 \mathrm{a}$ \\
\hline Triticale & $24.59 \pm 4.71 \mathrm{a}$ & $12.58 \pm 0.5 \mathrm{abc}$ & $2.83 \pm 0.18 \mathrm{a}$ & $1.27 \pm 0.02 \mathrm{a}$ & $0.244 \pm 0.01 \mathrm{a}$ \\
\hline Avena sativa & $21.52 \pm 4.95 \mathrm{a}$ & $13.19 \pm 0.76 b$ & $2.78 \pm 0.26 \mathrm{a}$ & $1.27 \pm 0.02 \mathrm{a}$ & $0.246 \pm 0.0229 a$ \\
\hline Secale cereale & $23.13 \pm 4.72 \mathrm{a}$ & $13.65 \pm 0.42 \mathrm{bc}$ & $2.98 \pm 0.22 \mathrm{a}$ & $1.26 \pm 0.02 \mathrm{a}$ & $0.231 \pm 0.0167 \mathrm{a}$ \\
\hline
\end{tabular}

Means within columns followed by the same letters are not significantly different (LSD, P > 0.05).

$\mathrm{R}_{0}$ : Net reproductive rate; T: Mean generation time; DT: Doubling time; $\lambda$ : Finite rate of increase; $\mathrm{r}_{\mathrm{m}}$ : Intrinsic rate of increase. 
The intrinsic rate of natural increase $\left(\mathrm{r}_{\mathrm{m}}\right)$ of viviparous apterae of $R$. padi was different among cereals $(\mathrm{P}<$ $0.05)$. The $r_{m}$ value was the highest on beer barley $(0.309$ nymphs per aphid $\mathrm{d}^{-1}$ ) compared to the aphids reared on the other cereals. This estimated value of the six cereals in the present study varied from 0.231 to 0.309 females per females per day. Finally, the lowest $r_{m}$ value was attained when the aphid populations were reared on rye (Table 2).

\section{DISCUSSION}

It is essential to understand the demographic parameters of a pest to develop an integrated pest management strategy. These parameters provide population growth rates of an insect pest in the current and next generations. It is known that several factors, such as host plant species, can influence the $R$. padi population growth rate (Hesler, 2005). Thus, this study was carried out to compare the biological and demographic parameters of $R$. padi.

In the present study, the survival of $R$. padi decreases continuously from day one until the last generations on all host plants (Figure 1). However, the lowest mortality was found on triticale, beer barley, and rye (Table 1). This could be due to a difference in leaf cuticle structure, the composition of the epicuticular lipids (Eigenbrode and Espelie, 1995), or different hydroxamic acid levels (Thackray et al., 1990).

Beer barley was the best host for $R$. padi. The high aphid performance on this cereal is mostly because of longer adult longevity (20.88 d) and the highest number of nymphs produced (41 nymphs). Similar longevity results (20 to $30 \mathrm{~d}$ ) and fecundity (42 nymphs) were recorded by Villanueva and Strong (1964). Conversely, the poor performance of the aphid on oat was due to poor fecundity and higher nymphal mortality (Table 1). These results indicate that oat could be a potential crop for the farmers in years when the increase of a $R$. padi population could be a serious problem.

The per capita growth $\left(\mathrm{r}_{\mathrm{m}}\right)$ of $R$. padi estimated in the current study ranged from 0.231 to 0.309 nymphs per aphid per day (Table 2). These values are close to those estimated for $R$. padi reared on winter cereals and other host plants at 0.263 nymphs per aphid per day (La Rossa et al., 2005), 0.280 nymphs per aphid per day at $24{ }^{\circ} \mathrm{C}$ (Auad et al., 2009) and 0.328 nymphs per aphid per day at $25^{\circ} \mathrm{C}$ (Taheri et al., 2010). High $\mathrm{r}_{\mathrm{m}}$ values indicate susceptibility of a host plant to insect attack while a low value indicates that the host plant species is resistant to attack. Therefore, our data show the tremendous growth capacity of $R$. padi populations on $H$. distichum under favorable conditions.

\section{CONCLUSIONS}

These results can provide valuable information about the population growth of Rhopalosiphum padi on cereal crops; they could serve as a basis to develop control strategies and subsequent improvement of management programs.

\section{ACKNOWLEDGEMENTS}

Financial assistance was provided by SECYT-UNS. We thank CONICET for granting a research fellowship to Carolina Sánchez Chopa.

Crecimiento poblacional de Rhopalosiphum padi $\mathbf{L}$. (Homoptera: Aphididae) sobre diferentes cereales de la pampa semiárida de Argentina en condiciones de laboratorio. El áfido Rhopalosiphum padi L. (Homoptera: Aphididae) es una de las principales plagas de numerosos cultivos de la región semiárida pampeana de Argentina. En el presente trabajo se estudió el efecto de diferentes cereales incluidos Triticum aestivum L., xTriticosecale Wittm., Hordeum vulgare L., Hordeum distichum L., Avena sativa L. and Secale cereale L. sobre los parámetros biológicos de $R$. padi en laboratorio. Se estimaron longevidad, tasa intrínseca de crecimiento natural $\left(r_{m}\right)$, tasa neta de reproducción $\left(R_{0}\right)$, tiempo generacional medio (T), tiempo de duplicación (TD), y tasa finita de incremento $(\lambda)$ del pulgón de la avena en diferentes cereales. Las diferencias de los parámetros biológicos de $R$. padi entre los distintos cultivos fueron analizadas utilizando pseudovalores con la técnica de Jackknife. Los resultados indican que la cebada cervecera podría ser el cultivo más preferido por este áfido debido a la larga longevidad (20,88 d), la alta fecundidad (41 ninfas hembra $\left.{ }^{-1}\right)$, la alta tasa de incremento natural $(0,309$ hembras hembra $\left.{ }^{-1} \mathrm{~d}^{-1}\right)$, el corto tiempo de duplicación $(2,24$ d) y la baja mortalidad ninfal $(22,2 \%)$. De los resultados obtenidos podemos inferir que $R$. padi tiene una mejor performance sobre la cebada cervecera que sobre el resto de cereales utilizados en este trabajo.

Palabras clave: tasa intrínseca, ciclo de vida, pulgón de la avena, cultivos invernales.

\section{LITERATURE CITED}

Auad, A.M., S.O. Alves, C.A. Carvalho, D.M. Silva, T.T. Resende, and B.A. Veríssimo. 2009. The impact of temperature on biological aspects and life table of Rhopalosiphum padi (Hemiptera: Aphididae) fed with signal grass. Florida Entomologist 92:569577.

Bailey, P. 2007. Pests of field crops and pastures identification and control. 520 p. CSIRO Publishing, Oxford, UK.

Birch, L.C. 1948. The intrinsic rate of natural increase of an insect population. Journal of Animal Ecology 17:15-26.

Blackman, R.L., and V.F. Eastop. 2000. Aphids on the World's crops. An identification guide. 414 p. $2^{\text {nd }}$ ed. J. Wiley \& Sons, Chichester, UK.

Borer, E.T., V.T. Adams, G.A. Engler, A.L. Adams, C.B. Schumann, and E.W. Seabloom. 2009. Aphid fecundity and grassland invasion: Invader life history is the key. Ecological Applications 19:1187-1196.

Eigenbrode, S.D., and K.E. Espelie. 1995. Effects of plant epicuticular lipids on insect herbivores. Annual Review of Entomology 40:171-194. 
Fabre, F., J.S. Pierre, C.A. Dedryver, and M. Plantegenest. 2006 Barley Yellow Dwarf Disease risk assessment based on Bayesian modelling of aphid population dynamics. Ecological Modelling 193:457-466

Gianoli, E. 2000. Competition in cereal aphids (Homoptera: Aphididae) on wheat plants. Environmental Entomology 29:213219.

Hansen, L.M. 2000. Establishing control threshold for bird cherryoat aphid (Rhopalosiphum padi L.) in spring barley (Hordeum vulgare L.) by aphid-days. Crop Protection 19:191-194.

Hasan, F., and M.S. Ansari. 2010. Population growth of Pieris brassicae (L.) (Lepidoptera: Pieridae) on different cole crops under laboratory conditions. Journal of Pest Science doi:10.1007/ s10340-010-0339-9

Hesler, L.S. 2005. Resistance to Rhopalosiphum padi (Homoptera: Aphididae) in three triticale accessions. Journal of Economic Entomology 98:603-610.

Hill, D.S. 2008. Pests of crops in warmer climates and their control. 708 p. Springer Science + Business Media, UK

Jiménez-Martínez, E.S., N.A. Bosque-Pérez, P.H. Berger, R.S. Zemetra, H. Ding, and S.D. Eigenbrode. 2004. Volatile cues influence the response of Rhopalosiphum padi (Homoptera: Aphididae) to Barley yellow dwarf virus-infected transgenic and untransformed wheat. Environmental Entomology 33:1207-1216.

La Rossa, R., y N. Kahn. 2003. Dos programas de computadora para confeccionar tablas de vida de fertilidad y calcular parámetros biológicos y demográficos en áfidos (Homoptera: Aphidoidea) Revista de Investigaciones Agropecuarias (INTA) 32:127-142.

La Rossa, R., A. Vasicek, P. Mendy, A. Moreno Kiernan, y A. Paglioni. 2005. Biología y demografía de Diuraphis noxia (Mordv.), Rhopalosiphum padi (L.) y Metopolophium dirhodum (Wlk.) sobre trigo en condiciones de laboratorio (Hemiptera: Aphididae). Boletín de la Sociedad Entomológica Aragonesa 36:227-231.

Maia De, A.H.N., A.J.B. Luiz, and C. Campanhola. 2000. Statistical inference on associated fertility life table parameters using Jackknife technique: computational aspects. Journal of Economic Entomology 93:511-518.
Östman, Ö., B. Ekbom, and J. Bengtsson. 2001. Heterogeneity and farming practice influence biological control. Basic and Applied Ecology 2:365-371.

Qureshi, J.A., and J.P. Michaud. 2005. Interactions among three species of cereal aphids simultaneously infesting wheat. Journal of Insect Science 5:13.

Riedell, W.E., R.W. Kieckhefer, M.A.C. Langham, and L.S. Hesler 2003. Root and shoot responses to bird cherry-oat aphids and Barley yellow dwarf virus in spring wheat. Crop Science 43:13801386.

Schotzko, D.J., and N.A. Bosque-Pérez. 2000. Seasonal dynamics of cereal aphids on Russian wheat aphid (Homoptera: Aphididae) susceptible and resistant wheats. Journal of Economic Entomology 93:975-981.

Soil Survey Staff. 1999. Soil taxonomy. $2^{\text {nd }}$ ed. USDA Agriculture Handbook $\mathrm{N}^{\circ} 436.869 \mathrm{p}$.

Soleimannejad, S., Y. Fathipour, S. Moharramipour, and M.P. Zalucki. 2010. Evaluation of potential resistance in seeds of different soybean cultivars to Helicoverpa armigera (Lepidoptera: Noctuidae) using demographic parameters and nutritional indices Journal of Economic Entomology 103:1420-1430.

Soufbaf, M., Y. Fathipour, J. Karimzadeh, and M.P. Zalucki. 2010 Development and age-specific mortality of diamondback moth on Brassica host plants: pattern and cause of mortality under laboratory conditions. Annals of the Entomological Society of America 100:574-579.

Southwood, T.R.E., and P.A. Henderson. 2000. Ecological methods, with particular reference to the study of insect populations. $575 \mathrm{p}$ $3^{\text {rd }}$ ed. Blackwell Science, Oxford, UK.

Taheri, S., J. Razmjou, and N. Rastegari. 2010. Fecundity and development rate of the bird cherry-oat aphid, Rhopalosiphum padi (L.) (Hom.: Aphididae) on six wheat cultivars. Plant Protection Science 46:72-78.

Thackray, D.J., S.D. Wratten, P.J. Edwards, and H.M. Niemeyer 1990. Resistance to de aphids Sitobion avenae and Rhopalosiphum padi in Gramineae in relation to hidroxamic acid levels. Annals of Applied Biology 116:573-582.

Villanueva, J.R., and F.S. Strong. 1964. Laboratory studies on the biology of Rhopalosiphum padi (L.) (Hemiptera: Aphididae). Annals of Entomologic Society of America 57:609-613. 